\title{
Interscience Management Review
}

Volume 3 | Issue 1

Article 2

January 2010

\section{Survey of E-Governance Systems with focus on Development Approaches and Interface Quality}

\author{
G. Rani \\ Netaji Subhas Institute of Technology, Dwarka, Sector 3, New Delhi, geetachhikara@gmail.com \\ S. Chakraverty \\ Netaji Subhas Institute of Technology, Dwarka, Sector 3, New Delhi, apmahs@rediffmail.com
}

Follow this and additional works at: https://www.interscience.in/imr

Part of the Business Administration, Management, and Operations Commons, and the Human Resources Management Commons

\section{Recommended Citation}

Rani, G. and Chakraverty, S. (2010) "Survey of E-Governance Systems with focus on Development Approaches and Interface Quality," Interscience Management Review. Vol. 3 : Iss. 1 , Article 2. DOI: 10.47893/IMR.2010.1042

Available at: https://www.interscience.in/imr/vol3/iss1/2

This Article is brought to you for free and open access by the Interscience Journals at Interscience Research Network. It has been accepted for inclusion in Interscience Management Review by an authorized editor of Interscience Research Network. For more information, please contact sritampatnaik@gmail.com. 


\title{
Survey of E-Governance Systems with focus on Development Approaches and Interface Quality
}

\author{
G. Rani \& S. Chakraverty \\ Division of Computer Engineering, Netaji Subhas Institute of Technology, \\ Dwarka, Sector 3, New Delhi-110078, India \\ E-mail: geetachhikara@gmail.com, apmahs@rediffmail.com
}

\begin{abstract}
There has been a significant growth of e-governance systems in general and online voting systems in particular. Various models have been proposed to conceptualise and develop these systems. Attention is currently on developing adaptive interfaces that respond intelligently to changes in user profiles. These models differ in many aspects, but no formal classification or comparative study is available as yet which may be used as a reference for researchers engaged in this area. This paper surveys the plethora of existing approaches and models for e-governance and presents a comparative evaluation based on certain qualitative parameters. These parameters have been selected based upon their criticality in e-governance applications. They include security, interoperability, authentication, flexibility, extensibility, privacy, adaptability, transparency, verifiability and robustness. The classification provides a common platform to glean knowledge about the strengths and weaknesses of different models, gain a quality-based comparative evaluation and build upon specific research directions.
\end{abstract}

\section{INTRODUCTION}

Electronic governance is a growing phenomenon within public sector institutions around the world. It provides an easy, fast, economical and transparent way of disbursing government services to public, government employees and businesses alike. It is the mandate of Governments-online to deliver their services and programs efficiently, provide governmental information and interact with citizens, all electronically [1,2]. Some of the successful applications of e-governance are rural banking for loans disbursement [3], grass-roots level online education, e-democracy $[4,5,6]$, disaster management for distribution of medical and financial aid [8,9] and transport system for ticketing and crew management [10].

In the next section, we present the background for e-governance. Here we will outline different types of e-governance delivery systems, applications and take up e-voting as a case to mull the critical quality parameters. In section 3, we review the various existing e-governance models by classifying them along three dimensions; online and offline systems, development approaches and quality of user interface. In section 4, we present a comparative evaluation of these models based on the quality parameters discussed in section 2. Finally we conclude in section 5 .

\section{BACKGROUND}

\subsection{Delivery models}

E-Governance delivery systems [11,12,13] adopted by different countries can be classified broadly as below:
Intra Governmental systems (G2G): These systems allow different governmental departments to interact with each other seamlessly. It improves efficiency as well as transparency of operations.

Government and Business (G2B and B2G): These solutions enable the government to deal effectively with a gamut of commercial transactions and e-commerce such as tendering, licensing, and infrastructure project management etc.

Governmental services to citizen (G2C \& C2G): These delivery systems are based on the premise that the government-citizen relationship is a business-customer relationship. It implements various Customer-RelationsManagement (CRM) processes. Services such as filing tax returns, issue of passports, registration of property, birth, marriage and death and providing driving licenses have been rendered smooth and transparent due to their online implementation. .

Government and foreign affairs (G2X): Various functions related to foreign trade, tourism and cultural/academic exchange programs are executed online, thus boosting international cooperation. These include repatriation of foreign earnings, foreign investments, work permits, hotel bookings and organizing international events.

\subsection{Applications}

Countries all over the world have adopted e-governance policies[14,15] to great advantage. Some success stories are listed below: 
- Online voting was first allowed in the small Baltic republic of Estonia in their 2005 committee elections[16]. Since then, Estonia carried out online voting in further parliamentary elections and European parliament elections [17]. Norway and Switzerland will run online e-voting pilots in September 2011 and October 2011 respectively. It is expected that many countries will follow in the same direction.

- Launching of Citizen Facilitation Centres (CFCs) [18] has increased revenue collection from Rs 38.63 crore in 2003 to Rs 54 crore in 2005.

- The pilot project offered a corruption online reporting facility in six towns and two remote locations in Kenya[19].

In India, the government provides IT-enabled services [20] to citizens in several areas such as agriculture[21], education, banking, democratic processes, health services and tax payment. We review some sample applications below.

- Karnataka: The Karnataka government's 'Bhoomi' project has led to computerisation of centuries-old system of handwritten rural land records, thus systematising the revenue department's land records of Right, Tenancy and Cultivation (RTC) [22].

- Gujarat: Gujarat has launched websites for all major departments where citizens log on and get access to data and issues related to the concerned government department as land water and taxes [23].

- Andhra Pradesh: The 'e-Seva' portal of Andhra Pradesh facilitates citizens to pay water, electricity, telephone bills and municipal taxes online [24]. It also provides the facility of online birth and death registration, passport applications, permits, licences, transport department services and reservation.

- Madhya Pradesh: The District Council of Dhar in the state of Madhya Pradesh put up an intranet under a project named "Gyandoot" to help farmers and villagers transact their services online with the government of the province and district councils $[25,26]$.

The above examples indicate some dominant features of e-governance applications. Several applications share data and communicate with each other. Interoperability and standardization are thus indispensable. The different stake-holders such as governments, businesses and citizens span different regions and languages. Therefore these applications need a flexible, user friendly and adaptable interface. We next take up online voting as a sample system to understand the quality parameters relevant to e-governance systems.

\subsection{Quality parameters}

Let us now consider the various quality parameters that influence the design of e-governance systems. Since a wide gamut of applications exist, we shall take up evoting as a sample application and investigate the critical quality factors involved therein. Online voting entails the ability to vote from any location by using the internet [27]. It can increase voter participation without people having to join queues, allow voting from remote areas by military personnel and people living abroad, avoid postal delays and human errors in vote counting and bring faster results.

\subsubsection{Protection issues}

Insecure communication channels can provide unauthorised access to e-governance systems. An active fraudulent agent can detect the identity of voter when he/she is sending information through the network, thereby compromising his/her privacy[27]. E-governance systems must protect the site from illegal access and also protect sensitive user information. Protection relates to the following issues:

- Security: Security ensures that the data transferred between sender and receiver is not leaked or tampered with anywhere in between. Encryption and decryption algorithms and digital signatures allow secure transmission of cipher text.

- Anonymity: In some applications like e-voting, the identity of an online voter must be hidden even from the system administrator.

- Verifiability: The voter must be able to verify that her vote has been correctly stored in memory against her digitized entity. Anonymity and verifiability are often mutually conflicting issues that cannot be resolved simultaneously.

- Authentication: To ensure only valid votes, voters must be authenticated before the voting stage by digital signatures, smart cards or unique Personal Identification Number (PIN).

- Fraud detection: Access by fraudulent agents is a major issue as it decreases reliability and trust of people in the system. One way of tackling this issue is by monitoring the behaviour of users and storing the regular expected behaviour in the database. Unexpected behaviour shows that the user is fraudulent.

\subsubsection{Democratization issues[28]}

One of the objectives of online voting is to encourage wider participation in the democratic process. 
- Information systems for elections: So far, online voting models dealt with different phases of voting such as registration phase, voting phase and counting phase. Newer online voting systems can enhance democratization by providing a complete information system on the election process by including an intelligent query response system, dynamic updates, visualization of results and online training for system operators and the public.

- Transparency: As more software is used, its trustworthiness becomes a major concern. All components of the software, including the code, compiler, installation mechanism and delivery should be validated and open to public scrutiny.

- Adaptive interfaces: Online voting systems must cater to a very large population with diverse educational and economic backgrounds. The digital divide is also of concern. Therefore, the interface design is a key issue. The system should be able to provide an appropriate interface according to the category of users. The interface must be flexible so that it is able to take inputs from various sources and work with different standards.

\subsubsection{System design issues}

Adopting excellent design principles cull out costly errors that may otherwise be hard to rectify at later stages. The following parameters must be kept in mind during system design.

- Reusability[28]: Since e-governance is an emerging area, it is expected that newer and more sophisticated applications will continue to be developed. It is beneficial to utilize past developmental efforts and learn from past experiences. Therefore, development methods that enhance reusability must be adopted. Design patterns based frameworks is a good approach towards development of e-governance systems.

- Interoperability and standardization: Online voting systems employ several servers that manage various types of data and services. It is important to maintain interoperability[29] among these components. Well-defined quality standards[30] for different e-voting processes facilitate cooperative services, allow data sharing and free customers from dependence on specific vendors.

- Reliable design[31]: Reliability entails that the hardware and software subsystems are functioning properly and correct outputs are generated every time. Fault tolerant design employing hardware and/or software redundancy increases reliability albeit at a higher cost. Votes already committed to memory must be protected under any cost and any attempts at tampering must be immediately detectable. Thus, online error-detection techniques must be incorporated at the design stage.

- Scalability:[32] The system should be scalable with an increase in number of users and requirements.

- System data integrity[33]: In online voting system various servers are used for different purposes like registration server, voting server, counting server. It is necessary to maintain database integrity among all the servers as a complete system.

The quality attributes discussed above affect the system globally and are generic in nature. Therefore, they can be easily extended to other e-governance applications.

\section{CLASSIFICATION AND REVIEW OF E-GOVERNANCE MODELS}

Classification of various e-governance models is important as it provides a common comparative platform for researchers and developers. We undertake three approaches for classification of e-governance models: Online versus offline approaches for e-voting, development methods adopted in e-governance systems and approaches based on the interface quality.

\subsection{Online versus offline approaches for e-voting}

Offline systems, historically developed first, still enjoy users' trust as they are free from cyber attacks unlike online systems $[34,35]$ that can compromise privacy of users and cause unauthorized access of data and malicious attacks. Nevertheless, online systems are in great demand due to their interactivity and location independence.

\subsubsection{The Offline Electronic Voting Machine [36, 37]:}

The offline EVM e-voting systems are currently used for voting in India. Its software has been programmed in assembly language. It consists of two interconnected parts; the Ballot unit allows voters to input their votes by pressing a button and the Control unit maintains reliability of the system and displays results after closing of election.

\subsubsection{Online approaches[38,39,40]:}

Most of the current e-governance systems are online. We review some of the online models below:

Tamper evident storage for e-voting [41]: The authors have used reusable formal design methods like Event-B, Manchester encoding for PROM technology and write once data technology to maintain the accuracy of online vote-storage. These methods ensure tamper evident storage of votes to prevent addition of unauthorised votes after the election and change or deletion of already 
validated votes. The "correct by construction refinement technique" along with its proof tool is used to make the system transparent and open. However detection of tampering is possible only after end of the election.

Rijnland Internet Election System[42]:The RIES system proposed integration of e-voting with ordinary mail voting system by including voter's feedback system, keyless hashes, technical votes and shadow system. This makes the RIES highly transparent and verifiable. However, security can be compromised due to possible hacking of domain name server while voting and modification of the java script in which cryptographic computations are done in the web browser downloaded in the voter's computer.

A Robust Electronic Voting System [43,44]: The REVS protocol includes mutually exclusive phases such as ballot distribution, ballot signing, ballot submission and counting phases to maintain privacy of the voter. Use of a blinding factor, the election's public key, a randomly generated symmetric session key and the election's private key support the removal of redundant and invalid votes after the election and counting of only valid votes. The system also provides the facility to resume a previous state the voter saved in a checkpoint in case of communication failure while voting. However, the system is sensitive to external and internal attacks which may corrupt the operating system or network stack to allow submission of invalid votes and resubmission of valid votes.

Fujioka approach [45]: The voting system proposed in [45] consists of three central facilities: registrar, validator and tallier, and seven election phases: registration, preparation, authorisation, voting, collecting, opening and counting. The separation of concerns thereby implement privacy and fairness by ensuring no way to find the relation between a vote $v i$ and its voter $V i$. The system may however compromise security because it assumes that the communication channel is anonymous. Besides, the counters may overflow with invalid votes without being detected during the election hours as they are detected only at the end of the election.

Sensus approach [46]: Inclusion of an extra central facility the pollster to the Fujioka approach supports the simultaneous casting and counting of votes. Invalid votes can be detected during the election hours. Once again, security may be compromised due to assumption of anonymous communication channel and use of blind signatures on a large scale. In [47] the tallier can replace some of the votes in case of selection of same random keys and votes by two or more voters.

Improved Sensus approach [46]: In a bid to remove the anomalies of the Fjioka and Sensus approaches and increase security, this approach employs six central facilities viz. registrar, counter, distributor, authenticator, matcher and verifier. A high degree of security and system integrity is maintained by prescribing welldefined roles for each entity and ensuring that none encroaches upon sanctified information with another. It also maintains the anonymity of the voter by using secure communication channel like HTTPS in Netscape for each transaction.

\subsection{Classification based on development approaches}

A variety of development approaches have been tried out by different researchers leading to specific benefits like extensibility, interoperability and ability to change the system with changing requirements. Here we examine the main approaches.

\subsubsection{A UML based 4-Step Rule Set approach $[47,48]$}

In 4-SRS method, the author proposes step-wise transformation of the informal requirements gathered from domain experts and users into an abstract model of system requirements. Object creation, object deletion, object aggregation/packaging and object association are the four steps employed to transform UML architecture to a semantically consistent object oriented architecture. The object model is further transformed into logical model to capture functional requirements, non functional requirements and support design decision. This approach is useful in designing service oriented e-governance systems. But it requires unfolding of use case hierarchy which increases the time complexity.

\subsubsection{Architectural and design patterns based approaches}

E-governance frameworks[49]: Based on the observation that different countries implement their egovernance solutions using the same basic concepts under different contexts, the authors employed commonality analysis to investigate e-government ontology and reusable knowledge. Knowledge mapping, pattern recognition and mind mapping techniques are used to identify the boundaries of e-governance systems. These systems use architectural and framework patterns, governance patterns to design the structure of egovernance systems and implementation patterns to solve problems beyond design phase like portal content creation and management.

Frameworks such as E-governance Interoperability Framework (e-GIF) [50], Estonian IT Interoperability Framework (EE-GIF) in Estonia[51] and New Zealand's e-Governance Interoperability Framework (NZ eGIF)[52] are used to maintain data integrity, interoperability in heterogeneous data, to define technical policies and for content management. Differences in culture and administration of various countries are still 
wide enough to make the generalization of e-governance systems difficult.

Layered Software approach [53]: In [53] the authors propose four interdependent contextual layers to handle their specific assigned functions. The business process layer implements high level business rules, the data architecture layer handles data types and formats, the application architecture layer deals with performance requirements and technology infrastructure deals with hardware and software resources. Well defined protocols such as JDO, EJB and DAO for business layer, RDBMS, ODBMS, XML and ERP for data architecture layer and VPN, SSL and PKI for security govern inter layer communication. The layered approach is excellent for designing transparent and flexible e-governance systems.

In [53] technical and data format open standards such as XML have been used to allow seamless integration of new services to an existing e-governance system. Digital signatures, encryption password and access control systems are used to maintain security. Single-point Sign On (SSO) provides a single point of entry to all users while using National Gateway to interconnects different states. Of course, the high degree of interoperability incurs high cost of implementation and greater system complexity.

Using Design patterns [53,54,55,56,57]: In [54] Case Based Reasoning (CBR) and Formal Concept Analysis (FCA) based design pattern retrieval tools have been used to automatically extract suitable design patterns and thus reduce development efforts. CBR analyses problems mathematically and does not utilize knowledge from previously solved problems. FCA is used to find the conceptual relation between analysed data sets. FCA generates a concept lattice to show knowledge dependence between all the knowledge cases. In the relational database, knowledge cases or Objects $(G)$ are rows and design patterns used by them are their attributes (M). Incidence(I) is a subset of G X M. This approach is user interactive and refines the problem on the basis of user feedback. However, it is not useful for retrieval of design patterns if no related solved problem is available in the knowledge case database.

In $[55,56]$ the authors make use of decorator, observer and chain of responsibility design patterns in combination, to design a common framework for egovernance applications. An abstract class is defined for defining the basic functions of an e-governance system and concert classes are defined to describe the functionality which varies from application to application. Decorator pattern is used to assign dynamic responsibilities. Chain of responsibility pattern is used to keep privacy and enforce indirect communication. Observer pattern is used to provide flexible communication between sets of publishers and subscribers.

WebML based approach[58]: The paper uses WebML, a model driven approach assisted by visual design aids in the CASE tool Web Ratio is used to resolve the problems of joint design and developmental procedures of egovernance systems. Pre existing design patterns are mined from XML specifications of the WebML conceptual schema using XSL and graph mining techniques, thus enhancing code reusability.

\subsubsection{Agile and eXtreme programming approach[59]}

Countries that are new entrants to the e-governance arena employ agile and eXtreme Programming (XP) for fast development cycles and to efficiently incorporate continuous changes in requirements. The idea is to develop small service oriented modules and get continuous feedback from users. The SOMF (Service Oriented Modelling Framework) is used for successful implementation of Service Oriented Architecture.

\subsection{Classification based on Interface Quality}

Given the much increased participation of users in egovernance systems, a classification based on interface quality merits attention. Very few of them have static interfaces and almost all have dynamic features for user interactivity. Now, the focus is on designing user adaptive interfaces.

\subsubsection{Non adaptive interface [60]}

The paper [60] uses Lowest Common Denominator (LCD), Most Popular Interface (MPI) and Negotiated (N/A) behavioural design patterns to develop a common interface by normalizing them in terms of data model and extracting common methods from them to wrap the functionalities in common interface. The design pattern interface system cannot display large amounts of content in limited area.

The approach in [60] uses a model based interface development using ASP.NET. It creates a complex interface by customising and defining the UIDP < data set, property set, action set, present set $>$ [60]. Thus the approach is successful in designing customised complex interface. However, it does not support target code generation based on different platforms.

\subsubsection{Adaptive interface[61,62,63]}

Biclustering algorithm [61,62]: The main theme here is the analysis of the online behaviour of users and presenting information accordingly. The activities of online users are stored in log files and the proposed biclustering algorithm is applied to analyse them by mining navigation patterns, activities performed and time taken. The knowledge extracted is used to design an adaptive online application having better usability. 
Apache servers and database servers are used to store the filtered daily activities of online users which may be collected from e-mails sent by online users to communicate with each-other. The data collected is divided into clusters containing similar information by using mining and clustering algorithms. The main problem here is the increased time complexity due to large, complex and heterogeneous data sets.

\section{COMPARATIVE EVALUATION}

Based on our discussion of critical parameters in the previous section 2, we use them to present our comparative evaluation as summarized in Table 1.

\section{CONCLUSION}

We classified existing work along three important dimensions, viz offline-online approaches for e-voting systems, development approaches and interface quality.
We presented a comparative evaluation of models of egovernance systems based on critical quality parameters. Our analysis in table I and II shows that historical offline models of e-voting are being replaced by online models. Architectural and design patterns for software development allow reuse of existing code and enhanced scope for future extensions. More significantly, new egovernance systems are being quickly developed by agile and eXtreme programming that also allow user feedback to be quickly converted to new requirements and duly incorporated into the system. Interface designs have graduated from static to dynamic and now adaptive interfaces. Interface design attempt to bind legacy systems and also support smooth display of complex, voluminous information.

Table I

E-Voting models

\begin{tabular}{|c|c|c|c|c|c|}
\hline Title of & Parameters & & & & \\
\hline & Transparenc-y & Security & Verifiability & Privacy of user & $\begin{array}{l}\text { Authent-ication of } \\
\text { user }\end{array}$ \\
\hline $\begin{array}{c}\text { Fujioka } \\
\text { (1992) } \\
{[46]}\end{array}$ & $\begin{array}{l}\text { High, Voter can } \\
\text { check status of } \\
\text { his vote }\end{array}$ & $\begin{array}{l}\text { Low(communication } \\
\text { channel is assumed } \\
\text { anonymous ) }\end{array}$ & $\begin{array}{l}\text { High( voter } \\
\text { can verify the } \\
\text { result) }\end{array}$ & $\begin{array}{l}\text { Low(may be } \\
\text { compromised in case } \\
\text { of anonymous } \\
\text { communication } \\
\text { channel) }\end{array}$ & $\begin{array}{l}\text { High (authentic-ator and } \\
\text { registrar authenticate } \\
\text { valid voters only) }\end{array}$ \\
\hline $\begin{array}{c}\text { Sensus } \\
(1999) \\
{[47]}\end{array}$ & $\begin{array}{l}\text { High (possibility } \\
\text { of vote checking } \\
\text { by voter) }\end{array}$ & $\begin{array}{l}\text { Low(communication } \\
\text { channel is assumed } \\
\text { anonymous) }\end{array}$ & $\begin{array}{l}\text { High(voter can } \\
\text { verify the } \\
\text { result at end of } \\
\text { the election) }\end{array}$ & Low & High [Fujioka] \\
\hline $\begin{array}{l}\text { Improved } \\
\text { sensus } \\
(1999) \\
{[47]}\end{array}$ & $\begin{array}{lr}\text { High(user r can } \\
\text { check whether } \\
\text { his/her vote has } \\
\text { been added or } \\
\text { not). }\end{array}$ & $\begin{array}{l}\text { High(use of secure } \\
\text { communication } \\
\text { channel like HTTP in } \\
\text { Netscape) }\end{array}$ & $\begin{array}{lr}\text { High(voter can } \\
\text { verify } & \text { the } \\
\text { result } & \text { even } \\
\text { during } & \text { the } \\
\text { election) } & \\
\end{array}$ & $\begin{array}{l}\text { High (only registrar } \\
\text { get the name of } \\
\text { voters in encrypted } \\
\text { form who has no key } \\
\text { to decrypt it) }\end{array}$ & High [Fujioka] \\
\hline $\begin{array}{l}\text { REVS } \\
(2003) \\
{[43,44]}\end{array}$ & $\begin{array}{l}\text { High(the voter } \\
\text { can verify that } \\
\text { his/her vote is } \\
\text { added or not) }\end{array}$ & $\begin{array}{l}\text { Low (sensitive to } \\
\text { internal as well as } \\
\text { external attacks. } \\
\text { Invalid vote casting is } \\
\text { also possible) }\end{array}$ & $\begin{array}{l}\text { High(result } \\
\text { verification is } \\
\text { possible) }\end{array}$ & $\begin{array}{l}\text { High(use of digital } \\
\text { signatures) }\end{array}$ & $\begin{array}{l}\text { High } \\
\text { (use of digital } \\
\text { signatures) }\end{array}$ \\
\hline $\begin{array}{l}\text { RIES } \\
(2005)\end{array}$ & High & $\begin{array}{lr}\text { Low(possible } & \text { hacking } \\
\text { of domain } & \text { name } \\
\text { server) } & \end{array}$ & $\begin{array}{l}\text { High(use of } \\
\text { keyless hashes } \\
\text { supports } \\
\text { verification) }\end{array}$ & High & $\begin{array}{l}\text { High(use of multifunc- } \\
\text { tion smart cards) }\end{array}$ \\
\hline $\begin{array}{l}\text { Tamper } \\
\text { evident } \\
(2007)\end{array}$ & $\begin{array}{l}\text { High(result can } \\
\text { be verified at the } \\
\text { end of election) }\end{array}$ & $\begin{array}{l}\text { High(resistant to vote } \\
\text { tampering ) }\end{array}$ & High & High & High \\
\hline
\end{tabular}


Table II

E-Governance models

\begin{tabular}{|c|c|c|c|c|}
\hline \multirow{3}{*}{$\begin{array}{l}\text { Title of Model used } \\
\text { Layered software } \\
\text { approach[53] }\end{array}$} & \multicolumn{4}{|c|}{ Parameters } \\
\hline & Adaptability & Interoperability & Flexibility & Extensibility \\
\hline & Not adaptable & $\begin{array}{l}\text { High, use of single } \\
\text { point sign on and } \\
\text { national gateway }\end{array}$ & High(use of XML) & $\begin{array}{l}\text { High(use of XML to } \\
\text { integrate new services) }\end{array}$ \\
\hline $\begin{array}{l}\text { Biclustering } \\
\text { algo(2004)[61,62] }\end{array}$ & $\begin{array}{l}\text { High(supports user's } \\
\text { behavior prediction) }\end{array}$ & $\begin{array}{l}\text { High(applicable for } \\
\text { various types of } \\
\text { users) }\end{array}$ & High & $\begin{array}{l}\text { High(New parameters } \\
\text { can be added for user } \\
\text { profiling) }\end{array}$ \\
\hline $\begin{array}{l}\text { Knowledge } \\
\text { mapping } \\
(2008)[49]\end{array}$ & $\begin{array}{l}\text { High (user profile } \\
\text { based systems can be } \\
\text { designed by suitable } \\
\text { pattern combination) }\end{array}$ & High & High & $\begin{array}{l}\text { High(use of design } \\
\text { patterns) }\end{array}$ \\
\hline $\begin{array}{lr}\text { WebML } & \text { based } \\
\text { approach(2008)[58] }\end{array}$ & $\begin{array}{l}\text { High(pattern mining } \\
\text { supports adaptable } \\
\text { system designing) }\end{array}$ & $\begin{array}{l}\text { High(use } \\
\text { interoperability } \\
\text { frameworks) }\end{array}$ & High & $\begin{array}{l}\text { High(use of Web ML } \\
\text { and design patterns) }\end{array}$ \\
\hline $\begin{array}{l}\text { CBR and FCA } \\
\text { based } \\
\text { approach(2009)[54] }\end{array}$ & $\begin{array}{l}\text { High(based on pattern } \\
\text { mining) }\end{array}$ & Low & High & $\begin{array}{l}\text { High(use of pattern } \\
\text { mining) }\end{array}$ \\
\hline $\begin{array}{l}\text { eXtreme prog } \\
\text { based(2010)[59] }\end{array}$ & $\begin{array}{l}\text { High(use of pattern } \\
\text { mining) }\end{array}$ & High & $\begin{array}{ll}\text { High } & \\
\text { (design } & \text { patterns } \\
\text { develop } & \text { flexible } \\
\text { systems) } & \\
\end{array}$ & $\begin{array}{lr}\text { High(reusability } & \text { of } \\
\text { design pattern based } \\
\text { systems) }\end{array}$ \\
\hline
\end{tabular}

\section{REFERENCES:}

[1] Shailendra C. Jain Palvia and sushil S. Sharma; “ EGovernment and E-Governance: Definition /Domain Framework and status around the world"; 2007

[2] Mary Maureen Brown, Jack Robin(ed); "Electronic Government”, Enclyclopedia of public Administration and public policy, Dekker, 2003.pp:427-432

[3] Dr. Amrit patel ; "Rural banking policy, India Timely \& Effective use of technology and FI \& FIT funds needed” IEEE2008.

http://www.afminetwork.org/fichiers/ressources/rua l-20banking-20policy-20in-20india.pdf

[4] StevenClift;“Democracyisonline”,March/April1998; http://www.publicus.net/articles/democracyisonline. html

[5] Janet caldow; “e-Democracy putting down global roots”,January2004;http://www01.ibm.com/industri es/government/ieg/pdf/edemocracy\%20putting\%20 down\%20roots.pdf

[6] Jakob Linaa Janson; "Minnesota e-Democracy survey report”2002; http://www.edemocracy.org/ research/edemsurvey2002-jakobjensen.pdf
[7] Akbar S Ahmed; “Automating Government with eGovernance”, May 2004;

http:/www.linuxjournal.com/article/7591

[8] Chanuka wattegama "ICT for disaster management”, 2007; http://www.unapcict.org/ ecohub/resources/ict-fordisastermanagement; eprimerd.pdf

[9] Mifan Careem, Chamindra De Silva, Louiqa Rashid, Sanjiva Weerawarana; "Sahana: Overview of disaster management system”, International conference on Information and Automation; December2006,Colmbo,Srilanka;http://ftp.cfar.umd .edu/pub/louiqa/PUB06/Sahana6.pdf

[10] Silvio Di Re, Andrea compagna, Umberto Nanni; "A reference architecture for freight transport management systems”; http://www.freightwise.info/ cms/Content/download/A-reference-architecturefor-freight-transport-management-systems.pdf.

[11] Bharat Maheshwari*, Vinod Kumar, Uma Kumar and Vedmani Sharan; "E-Government Portal Effectiveness: Managerial Considerations for Design and Development", Published: Computer society of India; http://www.csisigegov.org/ 1/27.pdf 
[12] Sundresan Perumal, Norita Md Norwawi, Subramaniam Muniandy; “ The success transmission model from governance to egovernance"?

[13] Sriram Kavikondala, V Raman Rao Vishnubhotla, subba Rao Ghanta, Madhav Pulipati; "Data standardization for e-governance a practical approach", computer society of India; http://www.csi-sigegov.org/2/3_393_2.pdf

[14] T.V. Prasad; “e-Governance and standardisation”; IEEE TENCON2003; pg 198-202.

[15] Anil Monga, "E-Government: oppurtunities and challenges”;2008

[16] http://www.vvk.ee/voting-methods-inestonia/engindex, "Internet Voting in Estonia"

[17] "Online to the Ballot Box", The Swiss portal, 23 October,

2011”http://www.ch.ch/abstimmungen_und_wahlen /02186/02191/02334/index.html?lang=en

[18] Salil Khare; "E-governance: Success Story and the Way Ahead” http://www.csi-sigegov.org/ egovernance_pdf/ 1_1-5.pdf

[19] "E-governance capacity building" http://portal.unesco.org/ci/en/ev.phpURL_ID=6616\&URL_DO=DO_TOPIC\&URL_SE CTION=201.html

[20] "E-Governance:20 hot e-projects in India”;http://dqindia.ciol.com/content/top_stories/2 03101501.asp

[21] “Aboute-Chaupal”june-2000; http://www.echaupal.com/frontcontroller.ech

[22] www.bhoomi.karnatka.gov.in

[23] Vilasini Ramachandran ; "e-Dhara* :land Records Management system”, http://www.csisigegov.org/ casestudies/ 05_e_dhara.pdf

[24] www.esevaonline.com

[25] Dhar District, Official website of district administration, www.dhar.nic.in/GYANDOOT.htm

[26] http//www.mapit.gov.in

[27] Rachid Anane, Richard Freeland and Georgios Theodoropoulos; "e-Voting Requirement and Implementation”, I.C,IEEE(2007)

[28] Bhudeb Chakravarty, Vasudeva Verma; “An Enterprice architecture framework for building service oriented e-governance portal” ??

[29] Manish Pokharel, Jong sou Park; "Issues of interoperability in e-governance and its impact on developing countries: A Nepalese case study; Feb 15-18 2009, ICACT2009; pp 2160-2164.

[30] Suchitra Pyarelal;“Technical standards and egovernance architecture”;NIC-WG5-EGOVSTDSTSAGA; http://egovstandards.gov.in

[31] W. E. Carnes; "Highly Reliable Governance of Complex Socio-Technical Systems”; Deepwater Horizon Study Group -Working Paper - January 2011.

[32] Syed Nayyer Abbas Kazmi, "Factors Influencing EGovernance Implementation : Issues and Challenges in Pakistan”, IEEE(2010)

[33] John K.Akeson; “Assuring data integrity-An overview”, CH2682-3/89/0000-0217, 1989 IEEE.

[34] Naznin Fauzia, Tanima Dey, Inaba Bhuiyan, Md. Saidur Rahman; "An efficient Implementation of Electronic Election System”, IEEE(2007)

[35] Sanjay Saini, Dr. Joydip Dhar; “An eavesdropping proof secure online voting model”, IEEE 2008 International conference

[36] Jens-Matthias Bohli, Christian Henrich, Carmen Kempka, Jörn Müller-Quade, and Stefan Röhrich; "Enhancing Electronic Voting Machines on the Exampleof Bingo Voting”, IEEE transactions on information forensics and security, vol. 4, no. 4, December 2009.

[37] "The electronic voting machine-An electronic Marvel” http://www.indianelections.com/ electoralsystem/ electricvotingmachine.html

[38] Herschberg "Secure electronic voting over the World Wide Web”, M. 97, Master's Thesis Massachusetts Institute of Technology.

[39] Triinu Magi; "Practical security analysis of of evoting systems" Master thesis, Tallinn university of technology, 2007.

[40] Tadayoshi Kohno, Adam Stubblefield, Aviel D. Rubin, Dan S Wallach; "Analysis of an electronic voting system” Feb 2004, IEEE symposium on security and privacy 2004.

[41] Dominique Cansell, J. Paul Gibson; "Formal Verification of tamper-evident storage for eVoting”,IEEE(2004), Fifth IEEE conference on Software engineering and Formal methods, Published: IEEE Computer Society; DOI.10.1109/SEFM.2007.26; pg:329-338

[42] Engelbert Hubbers, Bart Jacob and Wolter Pieters; "RIES-internet Voting in Action”,(IC)IEEE 2005. 
[43] Joaquim, R. et al; “ REVS- A robust electronic voting system”, Proceedings of IADIS International Conference e-society 2003. Lisban, Portugal. Pp. 95-103.

[44] Ricardo Labre, Rui Joaquim, Andre Zuquete, Paulo Ferreira; "Internet Voting: Improving Resistance to Malicious Servers in REVS" IADIS International conference Applied Computing 2004.

[45] Atsushi Fujioka, Tatsuaki okamoto, Kazuo ohta; “A practical secret voting scheme for large scale elections”, Published: advances in cryptologyAuscrypt'92, Workshop on the theory and application of cryptographic techniques, Gold Coast, Queensland, Austeralia, December 1992 Proceedings.

[46] Jared Karro and JieWang; "Towards a practical, secure and very Large scale election”, 1999; http://www.acsac.org/1999/papers/thu-a-0830karro.pdf.

[47] Ricardo J. Machado, Paula Monteiro, Joao M. Fernandes and Halena Roderigues; "Transformation of UML models for service oriented software architectures", Published: proceedings of $12^{\text {th }}$ IEEE International conference on the engineering of computer based systems(ECBS’05).

[48] Ricardo J. Machado, Paula Monteiro, Joao M. Fernandes and Halena Roderigues; "Transformation of UML models for service oriented software architectures"; Published: proceedings of $12^{\text {th }}$ IEEE International conference on the engineering of computer based systems(ECBS’05).

[49] Majed Ayyad; "E-Government informatics", ICEGOV'08 Proceeding of the $2^{\text {nd }}$ international conference on Theory and practice of electronic governance.

[50] Cabinet office; "e-government interoperability framework 6.1”, 2005, accessed on28May2008 at http://www.govtalk.gov.uk/schemasstandardsegif.as ?page $=2 \&$ order

[51] Ministry of Economic Affairs and Communications, “Estonian IT Interoperability framework", accessed at http://www.riso.ee/eng/koosvoime.

[52] State service commission, "New Zealand interoperability framework(NZ e-GIF)”, 2008, accessed at http://www.egif.govt.nz.

[53] Narasimha Murthy D., Prasanna R.V.; "Software Architectural Design Model for e-Governance 1systems”, IEEE(2003)
[54] Weenawadee Muangon and Sarun Intakosum; "Adaptation of CBR and FCA using Design pattern retrieval tools”, $20094^{\text {th }}$ International conference on computer sciences and information technology; published: IEEE computer society DOI. 10.1109/ICCIT.2009.190.

[55] Ajay D. Parikh; "Software Design Pattern for EGovernance Solution" Proceedings of $4^{\text {th }}$ National conference; INDIA com2010.

[56] Tran D. Thu, Huynh T.B. Tran; “ A composite design pattern for object frameworks”, $31^{\text {st }}$ International computer software and application conference(COMPSAC2007), IEEE computer society.

[57] Phek Lan Thung, Chu Jian Ng, Swee Jing Thung, Shahida Sulaiman, "Improving a Web Application Using Design Patterns”, IEEE(2010).

[58] Yiannis Panagis, Evangelos Sakkopoulos, Athnasios Tsakalidis, Giannis Tzimas; "Techniques for mining e-government services to enhance end-user experience”, Int.J. Electronic Democracy, Vol.1,No.1, 2008.

[59] Shamal Roy and Mitu Kumar Debnath; "Designing SOA based e-governance system using eXtreme Programming methodology for developing countries"; $20102^{\text {nd }}$ International conference on software technology and engineering; 978-1-42448666-3/10; pg:V2 277-V2

[60] David E Millard, Yvonne Howard, Swapana Chennupati, Hugh C. Davis, Ehtesham-Rasheed Jam, Lester Gilbert, Gary B.Wills; "Design patterns for wrapping similar legacy systems with common service interfaces", Proceedings of the Europian conference on web services(ECOWS'06) 0-76952737-X-06, 2006 IEEE.

[61] Fatos xhafa,Leonard Barolli, Rozeta Miho, Santi caballe and Alberto Molina; "Using Bi-clustring Algorithm for Analyzing Online users Activity in a virtual campus”, 2010 International conference on networking and collaborative systems, IEEE computer society.

[62] Amos Tanay, Roded Sharan, Ron Shamir; “Biclustering Algorithms: A Survey”, May 2004.

[63] Anthony F. Norcio, Member and Jaki Stanley; "Adaptive Human Computer Interfaces; "A Literature Survey and prespective”, IEEE Transactions on man systems and cybernetics, Vol.19 No. 2,March/April 1989; pg:399-40. 